\title{
EXPLORATIVE STUDY OF M-COMMERCE AS A SMALL BUSINESS INNOVATION STRATEGY
}

\author{
Idris $^{*}$, , Khofifatu R. Adi*), and Agung Wiradimadja*) \\ *) Faculty of social science, Universitas Negeri Malang \\ Jl. Semarang No 05, Malang 65149, Indonesia
}

\begin{abstract}
MSMEs have proven to be part of the national economic backbone and have survived the economic crisis that has occurred in Indonesia. However, MSMEs are required to continue to innovate in their business strategies in the rapid disruption of business. The purpose of this study is to explore the role of m-commerce in MSMEs' business innovation strategies. By a qualitative descriptive approach, this study conducted at the Tempe Chips Center in Sanan in Malang as a case study. This study used primary (informants) and secondary (works of literature) data as sources of data and collected by using observation, interview, and documentation and used purposive sampling in determining the informants. Triangulation tests carried out in order to check data from various sources in various ways and times. This study found that the use of social media and the marketplace as one of MSMEs' business strategies in marketing products is still less than optimal. Although almost all MSMEs businesses use the Whatsapp application in their business transaction processes, only a few are expanding the market through other media. In general, MSMEs are familiar with social media and the marketplace, but few of them can optimize it in marketing their products.
\end{abstract}

Keywords: m-commerce, business strategy, business innovation, MSMEs

\begin{abstract}
Abstrak: UMKM telah terbukti menjadi bagian dari tulang punggung ekonomi nasional dan selamat dari krisis ekonomi yang terjadi di Indonesia. Namun, UMKM dituntut untuk terus berinovasi dalam strategi bisnis mereka dalam gangguan bisnis yang cepat. Tujuan dari penelitian ini adalah untuk mengeksplorasi peran m-commerce dalam strategi inovasi bisnis UMKM. Dengan pendekatan deskriptif kualitatif, penelitian ini dilakukan di Tempe Chips Center di Sanan di Malang sebagai studi kasus. Penelitian ini menggunakan data primer (informan) dan sekunder (literatur review) sebagai sumber data dan dikumpulkan dengan menggunakan observasi, wawancara, dan dokumentasi dan menggunakan purposive sampling dalam menentukan informan. Tes triangulasi dilakukan untuk memeriksa data dari berbagai sumber dengan berbagai cara dan waktu. Studi ini menemukan bahwa penggunaan media sosial dan pasar sebagai salah satu strategi bisnis UMKM dalam memasarkan produk masih kurang optimal. Meskipun hampir semua bisnis UMKM menggunakan aplikasi Whatsapp dalam proses transaksi bisnis mereka, hanya sedikit yang memperluas pasar melalui media lain. Secara umum, UMKM akrab dengan media sosial dan pasar, tetapi beberapa dari mereka dapat mengoptimalkannya dalam memasarkan produk mereka.
\end{abstract}

Kata kunci: m-commerce, strategi bisnis, inovasi bisnis, UMKM

\footnotetext{
${ }^{1}$ Corresponding author:

Email: idris.fis@um.ac.id
} 


\section{INTRODUCTION}

M-commerce has recently become a new business platform that not only plays a vital role in shifting the industry paradigm but also becomes an essential factor in the management of change and innovation in the future (Shin, 2017). M-commerce which is a product of the industrial revolution 4.0 provides enormous opportunities in business development in the digital age (Francesco et al. 2018; Nugraha, 2018; Roy et al. 2016; Shin, 2017). With faster and easier access to information (Francesco et al. 2018), M-commerce allows all business transactions to carried out without having to go through the presence of sellers and buyers. All processes can be transferred through computers and web services using smartphones. In addition to the ease and speed of the transaction accessibility process, M-commerce also provides a great opportunity for the industry to track and study customer behavior through big data obtained from customer transaction history. Thus, it is possible for companies to know the habits, lifestyle, and consumer behavior of customers and offer products according to what is needed by the customer (Francesco et al. 2018; Nieuwenhuis et al. 2018; Shin, 2017).

The existence of the phenomenon of the Internet of Things, all of which connected with the internet, allows the socio-economic dynamics to shift in such a way as quickly (Francesco et al. 2018) and also raises a new phenomenon known as a disruptive innovation (AlbertiAlhtaybat et al. 2019; Assink, 2006; Habtay, 2012; Hopp et al. 2018; Markides, 2006; Nieuwenhuis et al. 2018; Roy et al. 2016). Many incumbent companies or large companies begin to be disturbed by the presence of start-up companies that disrupt their markets and segments by offering more excellent services and at more affordable prices by end-users (Kasali, 2018).

A disruption phenomenon marked by an emergence of various innovative products, technologies, platforms, and business models. For an example of the disruption is the emergence of WhatsApp, which are opponents of the standard telecommunications operators. This platform issues free telephone and message services. Then, the emergence of Fintech slowly began to take the business segment of conventional banking. Besides, Gojek or Grab companies also began to disrupt conventional taxi service operators by providing a sharing business model, which is certainly more accessible and cheaper (Kasali, 2018). Thus, disruption, on the one hand, provides large profits and opportunities for micro, small and medium entrepreneurs (MSMEs) to be able to compete in marketing their products, but on the other hand, poses no small threat to the sustainability of MSMEs that are unable to follow and make innovations in their business strategies (Kasali, 2018; Nugraha, 2018).

MSME, as one of the movers and supporters of the national economy, cannot be denied to make a significant contribution to state revenue (Nugraha, 2018). It noted that the number of MSMEs in Indonesia in 2018 reaches 62,92 million business units or 99, $92 \%$ of the total existing business units in the country and contributes $60 \%$ of the country's gross domestic income (GDP), and can absorb 116 workers, 73 million people or $97,02 \%$ of the total workforce (Deny, 2018). However, of the total number of MSMEs, there are $36 \%$ of MSMEs are marketing their products offline, and only $18 \%$ have online capability using social media or the web, and only $9 \%$ can operate their businesses through e-commerce. If the involvement of MSMEs in e-commerce increases, it is predicted to increase revenue growth between 23-80\% (Deny, 2018; Widiarini, 2018). To support this, the government, through the ministries of cooperatives and SMEs has collaborated with 41 well-known market places such as blanja.com, mataharimall.com, Lazada, Shopee, Blibli, Tokopedia, Bukalapak, and others (Widiarini, 2018).

The contribution of MSMEs to the economy in East Java is also very significant. In the first semester of 2018, UMKM had contributed $5.57 \%$ of the total economic growth in East Java. Meanwhile, the contribution to the Gross Regional Regional Income (GRDP) of East Java at the current price reaches Rp544.44 Trillion with a predominance of support from the micro, small, and medium business sector. Meanwhile, investment realization in East Java reached Rp152.39 trillion in 2017, and Rp95.95 trillion in the first semester of 2018, up $22.87 \%$ from the previous year. Overall from 2017 to 2018, the contribution of MSMEs to total investment reached $56.34 \%$, and rose to $74.36 \%$ in Semester I, 2018 (Hakim, 2018).

MSMEs in Malang as one of the developing cities also have an impact that is no less significant, with the number of MSMEs that are not small. There are as many as 99, 213 micro, small, and medium businesses operating in Malang City (BPS Kota Malang, 2018). It noted in 2017, micro, small and medium enterprises contributed significantly to the regional income of 
Malang City by contributing 5,61\% to the economic growth of Malang City, more significant than the economic growth in East Java which was only 5, 5\% in the same year (Wahyunik, 2017). PDRB based on current prices in Malang City in 2017 amounted to 62, 190 billion with contributions from the micro, small, and medium business sector at $54.87 \%$ (BPS Kota Malang, 2018). Given the substantial contribution of MSMEs to the economy of the State, the province, and the region itself, MSMEs should be able to be a reliable economic driver.

The development of the technological era, with the advancement of the internet, requires MSMEs to adapt and innovate in business models developed by changing their business platforms through the use of the internet to be undisturbed and able to survive and develop as expected. However, the latest data shows that not a few of the SMEs in Malang, in their business strategy, still use the old methods. Of the total number of MSMEs, only $18 \%$ recorded using websites and social media as a means of promotion in their business (Deny, 2018). There are only about 5\% of the total MSMEs that utilize the marketplace (such as Tokopedia, Bukalapak, Olx, Shopee, and others). Apart from the role of leader, culture and HR (Idris, 2019; Idris and Adi, 2019; A. Sani et al. 2018; Achmad Sani et al. 2018), information technology provides high competitiveness to MSMEs (Prabandari and Azzuhri, 2011; Rahmana, 2009) and social media also have a very significant impact on improving the performance of small and medium businesses (SMEs) (Priambada, 2015; Siswanto, 2013; Widyaningrum, 2016). In other words, MSMEs required always to be able to adapt and innovate in a business strategy that carried out in order to survive and develop as expected (Purwadita et al. 2018). Therefore, this study aims to explore the role of $\mathrm{m}$-commerce in MSMEs' business innovation strategies and to describe the inhibiting and supporting aspects for MSMEs to implement those strategies. This study is critical to do in order to provide a deep understanding of various authorities in the development of MSMEs about the extent to which MSMEs choose adaptive and innovative business strategies by optimizing $\mathrm{m}$-commerce as a new platform in the business.

\section{METHODS}

This study used a descriptive qualitative approach that describes the phenomenon according to the research objectives (Sugiyono, 2017). This study used primary (informants) and secondary (literatures) data as sources of data and collected by using observation, interview, and documentation. This research conducted in Malang with the object of research was MSMEs in Malang. Criteria for MSMEs who become informants were micro, small, and medium business actors who have been in business for at least five years. The determination of the research object based on a purposive sampling technique by selecting and determining informants based on specific considerations (Sugiyono, 2017).

Data analysis carried out in 4 stages (Figure 1) by adapting the data analysis model of Miles and Huberman (1994), consisting of data collection, data reduction, data presentation, and conclusions or verification. Triangulation test carried out in order to check data from various sources in various ways and times. In detail, there are three types of triangulation tests, which include triangulation of sources, techniques, and time (Sugiyono, 2017).

\section{RESULT}

The purpose of this study is to explore the role of $\mathrm{m}$-commerce in MSME business strategies in Malang along with inhibiting and supporting factors in the use of $\mathrm{m}$-commerce in business strategies developed by MSMEs in Malang. There were 10 MSMEs involved in this study with the focus of the research object in the Sanan, MSME center area of Malang. The interviews conducted with the owner or the employees. Data regarding MSMEs provided in Table 1.

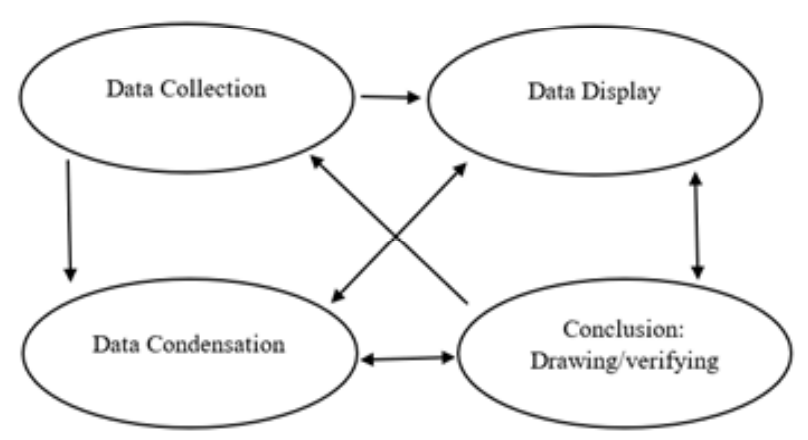

Figure 1. Interactive model of data analysis (Miles et al. 2014) 
Table 1 shows that there are at least 10 MSMEs that are sources of information on $\mathrm{m}$-commerce exploration studies as an MSME business innovation strategy in Malang. Besides, the table also explained that the type of business involved in this study was Kripik Tempe in Kampung Sanan, Purwantoro Village, Blimbing District, Malang City.

\section{The Role of M-Commerce in the MSME Business Innovation Strategy}

The use of advances in information technology in the form of marketplaces, social media, websites or blogs, and several other media as a place to market MSME business products is very much needed for MSMEs today. Consumer behavior that requires fast-food goods provides potential opportunities for businesses to optimize and maximize existing media to increase profits.

In general, several MSMEs involved in this study were aware of the existence of the media. Although, some of them also do not understand and do not utilize the existing marketing media for their products. More specifically, most of the MSMEs in Sanan only use the Whatsapp application as a communication medium for transactions with consumers. Meanwhile, some others have used social media such as Facebook, Instagram, marketplaces such as Tokedia, Bukalapak, and Shopee, as marketing media for their products. The following are the data regarding the use of m-commerce for MSMEs in the Kripik Tempe of Sanan.

Table 2 describes that the majority of MSMEs in Sanan has used and utilized mobile phone facilities as part of the marketing media of their products. This finding found from the use of the WhatsApp application as the favorite application of most MSMEs for the benefit of their product sales transactions. There is only one business, Kripik Tempe Fadilah, which completely markets its products offline. Besides, not only the WhatsApp application, some SMEs such as Tempe Rohani, Andika, Central, and Kiki Tempe have utilized social media and markets to market their products. However, this does not necessarily make them use this media in the SME business innovation strategy. The following are displayed data regarding the business strategy carried out by tempe chip business operators in Sanan.
Table 3 illustrates that almost all MSMEs continue to use ordinary strategies while maintaining the quality of taste. Besides, some add flavors, maintain prices, and trust and comfort the customer. Some even took part in the UMKM bazaar and gave bonus purchases in the form of stickers to introduce products to the market. However, only a few wants and has implemented electronic media such as social media, marketplaces, and other electronic media in their business strategies. As for this matter, as said by informants from the Tempe Kiki Production House and Kiki Tempe and Kripik Tempe Satriya that they use the media to expand their market coverage. Besides, there are also Karina tempe that use media to add channels in the form of Gojek in the sale of their products while Tempe Central and Andika Kripik want to adjust and re-use this media.

Table 1. MSMEs involved in the study

\begin{tabular}{|c|c|c|}
\hline Name & Address & Type of business \\
\hline $\begin{array}{l}\text { Keripik Tempe } \\
\text { Melati }\end{array}$ & $\begin{array}{l}\text { Jl. Sanan Gang } \\
\text { III, Purwantoro, } \\
\text { Blimbing, Malang }\end{array}$ & Keripik Tempe \\
\hline $\begin{array}{l}\text { Rumah Produksi } \\
\text { Cap Bawang }\end{array}$ & $\begin{array}{l}\text { Jl. Sanan Gang } \\
\text { III, Purwantoro, } \\
\text { Blimbing, Malang }\end{array}$ & Keripik Tempe \\
\hline $\begin{array}{l}\text { Rumah Produksi } \\
\text { dan Keripik } \\
\text { Tempe Kiki }\end{array}$ & $\begin{array}{l}\text { J1. Sanan No. } \\
\text { 33, Purwantoro, } \\
\text { Blimbing, Malang }\end{array}$ & Keripik Tempe \\
\hline $\begin{array}{l}\text { Keripik Tempe } \\
\text { Andra }\end{array}$ & $\begin{array}{l}\text { Jl. Sanan Gang } \\
\text { III, Purwantoro, } \\
\text { Blimbing, Malang }\end{array}$ & Keripik Tempe \\
\hline $\begin{array}{l}\text { Keripik Tempe } \\
\text { Satriya }\end{array}$ & $\begin{array}{l}\text { Jl. Sanan No } \\
\text { 99, Purwantoro, } \\
\text { Blimbing, Malang }\end{array}$ & Keripik Tempe \\
\hline $\begin{array}{l}\text { Keripik Tempe } \\
\text { Fadila }\end{array}$ & $\begin{array}{l}\text { Jl. Sanan Gang } \\
\text { III, Purwantoro, } \\
\text { Blimbing, Malang }\end{array}$ & Keripik Tempe \\
\hline $\begin{array}{l}\text { Keripik Tempe } \\
\text { Karina }\end{array}$ & $\begin{array}{l}\text { Jl. Sanan No. } 16 \\
\text {, Purwantoro, } \\
\text { Blimbing, Malang }\end{array}$ & Keripik Tempe \\
\hline $\begin{array}{l}\text { Keripik Tempe } \\
\text { Central }\end{array}$ & $\begin{array}{l}\text { Jl. Sanan No. } \\
\text { 24, Purwantoro, } \\
\text { Blimbing, Malang }\end{array}$ & Keripik Tempe \\
\hline $\begin{array}{l}\text { Keripik Tempe } \\
\text { Andika }\end{array}$ & $\begin{array}{l}\text { J1. R. Tumenggung } \\
\text { Suryo No. 84, } \\
\text { Sanan-Purwantoro, } \\
\text { Blimbing, Malang }\end{array}$ & Keripik Tempe \\
\hline $\begin{array}{l}\text { Keripik Tempe } \\
\text { Rohani }\end{array}$ & $\begin{array}{l}\text { J1. R. Tumenggung } \\
\text { Suryo No. 90, } \\
\text { Sanan-Purwantoro, } \\
\text { Blimbing, Malang }\end{array}$ & Keripik Tempe \\
\hline
\end{tabular}


Table 2. MSME using M-Commerce as business strategy

\begin{tabular}{|c|c|c|c|c|c|c|c|}
\hline Name & $\begin{array}{l}\text { Type of } \\
\text { business }\end{array}$ & M-commerce & Inf. & Name & $\begin{array}{l}\text { Type of } \\
\text { business }\end{array}$ & M-commerce & Inf. \\
\hline $\begin{array}{l}\text { Keripik } \\
\text { Tempe Melati }\end{array}$ & $\begin{array}{l}\text { Keripik } \\
\text { Tempe }\end{array}$ & Whatsapp & Active & $\begin{array}{l}\text { Keripik } \\
\text { Tempe Fadila }\end{array}$ & $\begin{array}{l}\text { Keripik } \\
\text { Tempe }\end{array}$ & Offline & Offline \\
\hline Rumah & Keripik & Whatsapp & Active & $\begin{array}{l}\text { Keripik } \\
\text { Tempe Karina }\end{array}$ & $\begin{array}{l}\text { Keripik } \\
\text { Tempe }\end{array}$ & $\begin{array}{l}\text { Whatsapp, } \\
\text { Gojek }\end{array}$ & Active \\
\hline $\begin{array}{l}\text { Produksi Cap } \\
\text { Bawang }\end{array}$ & Tempe & & & $\begin{array}{l}\text { Keripik } \\
\text { Tempe Central }\end{array}$ & $\begin{array}{l}\text { Keripik } \\
\text { Tempe }\end{array}$ & $\begin{array}{l}\text { Whatsapp, } \\
\text { MarketPlace }\end{array}$ & Active \\
\hline $\begin{array}{l}\text { Rumah } \\
\text { Produksi } \\
\text { dan Keripik } \\
\text { Tempe Kiki }\end{array}$ & $\begin{array}{l}\text { Keripik } \\
\text { Tempe }\end{array}$ & $\begin{array}{l}\text { MarketPlace, } \\
\text { Whatsapp, } \\
\text { Instagram }\end{array}$ & Active & $\begin{array}{l}\text { Keripik } \\
\text { Tempe Andika }\end{array}$ & $\begin{array}{l}\text { Keripik } \\
\text { Tempe }\end{array}$ & $\begin{array}{l}\text { Whatsapp, } \\
\text { MarketPlace, } \\
\text { Media sosial }\end{array}$ & Active \\
\hline $\begin{array}{l}\text { Keripik } \\
\text { Tempe Andra }\end{array}$ & $\begin{array}{l}\text { Keripik } \\
\text { Tempe }\end{array}$ & Whatsapp & Active & $\begin{array}{l}\text { Keripik } \\
\text { Tempe Rohani }\end{array}$ & $\begin{array}{l}\text { Keripik } \\
\text { Tempe }\end{array}$ & $\begin{array}{l}\text { Whatsapp, } \\
\text { Media sosial, } \\
\text { Website, }\end{array}$ & Active \\
\hline $\begin{array}{l}\text { Keripik } \\
\text { Tempe Satriya }\end{array}$ & $\begin{array}{l}\text { Keripik } \\
\text { Tempe }\end{array}$ & Whatsapp & $\begin{array}{l}\text { Marketplace } \\
\text { off }\end{array}$ & & & Marketplace & \\
\hline
\end{tabular}

Table 3. Business Strategy and Innovation against the Disruption Era

\begin{tabular}{|c|c|c|c|}
\hline Name & Initial strategy & Current strategy & Innovation \\
\hline Keripik Tempe Melati & Maintaining the quality of taste & $\begin{array}{l}\text { Maintaining the quality of } \\
\text { taste }\end{array}$ & Social Media \\
\hline $\begin{array}{l}\text { Rumah Produksi Cap } \\
\text { Bawang }\end{array}$ & Minimizing the selling price & Minimizing the selling price & Social Media \\
\hline $\begin{array}{l}\text { Rumah Produksi dan } \\
\text { Keripik Tempe Kiki }\end{array}$ & $\begin{array}{l}\text { Minimizing the selling price, maintaining } \\
\text { the quality of the taste, adding to the } \\
\text { flavor variants, joining the bazaar, and } \\
\text { purchasing bonuses }\end{array}$ & $\begin{array}{l}\text { Expanding market coverage } \\
\text { through the media }\end{array}$ & Social Media \\
\hline Keripik Tempe Andra & Maintaining the quality of taste & $\begin{array}{l}\text { Maintaining the quality of } \\
\text { taste }\end{array}$ & Social Media \\
\hline Keripik Tempe Satriya & $\begin{array}{l}\text { Maintaining the quality of taste and } \\
\text { keeping customer satisfaction }\end{array}$ & $\begin{array}{l}\text { Expanding market coverage } \\
\text { through the media }\end{array}$ & Social Media \\
\hline Keripik Tempe Fadila & $\begin{array}{l}\text { Maintaining the quality of taste and } \\
\text { customer loyalty }\end{array}$ & $\begin{array}{l}\text { Maintaining the quality of } \\
\text { taste and customer loyalty }\end{array}$ & Conventional \\
\hline Keripik Tempe Karina & Maintaining the quality of taste & $\begin{array}{l}\text { Adding variant of tastes and } \\
\text { market chain (Gojek) }\end{array}$ & Partnership (Gojek) \\
\hline Keripik Tempe Central & $\begin{array}{l}\text { Maintaining the quality of taste and } \\
\text { Adding variant of tastes }\end{array}$ & $\begin{array}{l}\text { Adapting by using market } \\
\text { place }\end{array}$ & $\begin{array}{l}\text { Social Media, } \\
\text { marketplace, gojek }\end{array}$ \\
\hline Keripik Tempe Andika & Maintaining the quality of taste & $\begin{array}{l}\text { Using social media and market } \\
\text { place }\end{array}$ & $\begin{array}{l}\text { Social Media and } \\
\text { marketplace }\end{array}$ \\
\hline Keripik Tempe Rohani & $\begin{array}{l}\text { Maintaining the quality of taste and } \\
\text { Adding variant of tastes }\end{array}$ & $\begin{array}{l}\text { Expanding market coverage } \\
\text { through the media }\end{array}$ & $\begin{array}{l}\text { Social Media and } \\
\text { marketplace }\end{array}$ \\
\hline
\end{tabular}

With regard to innovations in this competitive era, not all of the respondents innovate their business. Even the informants from Toko Melati said that they were only resigned to the quality of the taste of their products. This finding is almost similar as said by the informant from Kripik Tempe Andika, who only maintains the quality of taste and the selling price of their products.
M-commerce, as a new trade media as a result of the development of e-commerce, of course, also has the same ability to have a positive influence on business implementation. According to Hanum (2017), the adoption of this media can cause business performance to increase. Therefore, the use of this media should be able to play a role in business development strategies (Kim, 2006). 
Based on the data, it found that only half of the informants had improved strategies to keep their business on. They argue that it is necessary to adjust to these conditions starting from expanding market coverage and increasing purchasing channels. Both are forms of innovation strategy caused by encouragement from outside the organization (Tidd, 2001). First, market expansion is an activity to increase product marketing channels. This strategy included in one of the innovation strategies in the form of development (Schumpeter, 1934). The selection of this strategy considered adequate because the use of this media must be able to provide a new channel in marketing business products (Kim, 2006). This fact is because mobile penetration is unstoppable throughout the world (Hartati, 2011). Thus, this is not only local, but it has reached a global level in the marketing of these products. However, it should noted that the use of this media can only cover segments of buyers who have access to the internet (Lim et al. 2003).

Second, adding purchasing channels basically as a result of market expansion. With a vast market that even covers the world, regular payments or purchases directly to the store will be a difficulty. Therefore, with this media, the addition of channels for transactions will facilitate its implementation. This fact is because the flexible access given by m-commerce (Niranjanamurthy et al. 2013). Besides, with channel transactions through m-commerce, the costs incurred are less (Niranjanamurthy et al. 2013; Rahmidani, 2015).

The presence of M-Commerce has proven to have provided an increase in business strategy. However, this study also found that half of Tempe Chips business in Sanan did nothing to deal with this condition. It was the result of calculations of the factors that support and hinder the use of this media in their efforts.

\section{Inhibiting and Supporting Factors of MSME}

The use of social media and market places in marketing MSME products is an effort usually carried out by business actors to expand market segmentation and marketing reach of MSME products. However, not a few business actors still survive conventionally in marketing their products. There are several supporting and inhibiting factors for micro, small, and medium businesses in this regard.
Table 4 indicates that most MSMEs support the use of market place as a marketing medium for their products. As for almost all informants, they assume that by using this media, market coverage is getting wider. Besides, one of the informants also revealed that the use of this media reduces marketing costs. This finding is because there are several non-paid market places. Some even argue that with a market place, the selling price of the product is getting bigger. Thus, the business can get additional profit. This fact was revealed by informants who had used this media (Production House and Kiki Shop, Satriya Shop, Tempe Karina Chips, Tempe Central Chips, and Andika Tempe Chips) that they received additional profit, although a little and a bit complicated. Moreover, one informant also believes that this is important to be used to keep abreast of the times. However, on the other hand, there are still several things that are hampering so that businesses do not use or cannot optimize market places.

The obstacles that are felt by MSMEs to use the most significant market place are the purchases through this media tend to be few. As stated by an informant from Cap Bawang Production House that "The delivery of goods is only a unit, so it is a loss, many sales come directly to the store, and it is too long to make it online". Another informant from Melati Shop also said that "we sell offline only, there are already many buyers. Sales have directly taken goods". Besides, some informants also considered that using market place was timeconsuming. There are some informants who do not use this media because they do not understand the method and technology.

The use of m-commerce in the MSME innovation strategy has excellent possibilities. This opportunity is because m-commerce can answer the needs of the community quickly. Besides, the increased penetration of mobile phones throughout the world is also the reason this media has excellent support (Hartati, 2011). Therefore, to keep the UMKM business running, it is necessary to use this media to keep abreast of the times. The SMEs felt the same thing in Malang.

The implementation of an internet-based market (market place) proven to provide additional profit to business actors. The experience proves this that Kiki Shop and Satriya Stores, Tempe Karina Crips, Tempe Central Crips, Andika Tempe Cripts, and Andika Tempe Cripts have gained from the market place. This fact of course can also be felt by business people who want to use 
$\mathrm{m}$-commerce in their business moreover, if marketing costs through this media are free. As is also felt by the Fashion Industry in Belgium that the cost of web-based stores is cheaper when compared to conventional stores (Nauwelaerts and Chakri, 2016).

The biggest reason that supports MSME businesses in using $\mathrm{m}$-commerce in their businesses is that this media can provide a more comprehensive market coverage than conventional markets. This fact is because $\mathrm{m}$-commerce can provide new channels in marketing and retail (Kim, 2006). Even, it can access global markets (Rahmidani, 2015) only use their cellphones. This situation found to apply to almost all tempe chips business in Sanan. However, this is also what makes MSME entrepreneurs uncomfortable using m-commerce.

The higher the scope of the market, the further the delivery of products belonging to MSMEs can get. This scope is a barrier because it will reduce the profits that obtained. Especially if the number of orders from buyers is only small. Likewise, as felt by some tempe chip entrepreneurs in Sanan, one of which is the Tempika Ande Chips business especially if the case is the same as the Tempe Melati Kripik business, which has been overwhelmed to fulfill offline orders.

This media considered difficult to be used by some Tempe Chips business players in Sanan. One of the business owners (Kripik Tempe Fadila) felt that he was technologically illiterate. This weakness is supported by the statement of Niranjanamurthy et al. (2013) that "the appearance of the user's face tends to be difficult to understand how to use it." So, if implemented, this will drain the user's time though the use of technology, especially m-commerce expected to be able to provide time effectiveness for users (Niranjanamurthy et al. 2013). Therefore, it said that the benefits of m-commerce can achieved if the user can operate it and can access the internet (Lim et al. 2003).

\section{Managerial Implication}

It is important for the government, especially departments related to MSMEs providing programs that can improve the skills and knowledge of entrepreneurs in utilizing information technology to adapt and innovate in marketing their products to consumers.

Table 4. Supporting and inhibiting factors the use of market place

\begin{tabular}{|c|c|c|c|}
\hline Name & Supporting & Inhibiting & Inf. Market place \\
\hline Keripik Tempe Melati & - & Overloaded with offline orders & No \\
\hline $\begin{array}{l}\text { Rumah Produksi Cap } \\
\text { Bawang }\end{array}$ & Expanding market coverage & Only a few purchases & No \\
\hline $\begin{array}{l}\text { Rumah Produksi dan } \\
\text { Keripik Tempe Kiki }\end{array}$ & $\begin{array}{l}\text { Product prices are higher, expanding } \\
\text { market coverage }\end{array}$ & Technological Backward & No \\
\hline Keripik Tempe Andra & - & Overloaded with offline orders & No \\
\hline Keripik Tempe Satriya & Expanding market coverage & $\begin{array}{l}\text { Overloaded with offline } \\
\text { orders, Only a few purchases }\end{array}$ & Off \\
\hline Keripik Tempe Fadila & Expanding market coverage & Technological Backward & No \\
\hline Keripik Tempe Karina & Expanding market coverage & Technological Backward & No \\
\hline Keripik Tempe Central & Expanding market coverage & Only a few purchases & Active \\
\hline Keripik Tempe Andika & Free & $\begin{array}{l}\text { Only a few purchases, Any } \\
\text { problem with the payment } \\
\text { method }\end{array}$ & Active \\
\hline Keripik Tempe Rohani & A skilled and adaptable workforce & & Active \\
\hline
\end{tabular}




\section{CONCLUSIONS AND RECOMMENDATIONS}

\section{Conclusions}

The existence of m-commerce only plays a small role in the MSME business innovation strategy in Malang. The form of strategy taken by some business people is only in the form of expanding market coverage and the addition of business transaction channels through social media and marketplaces that can be accessed via mobile phones. This finding confirms Prabandari (2011) stating the effectiveness of the strategy depends on the context and business environment. However, this findings is on the contrary to the findings of Hanum (2017), Siswanto (2013), and Nauwelaerts (2016) that the use of electronic media can increase the turnover and performance of MSMEs. In addition, the supporting factors of using $\mathrm{m}$-commerce in their business is the ability of this media to reach markets, increase profits, and ease of use of mobile phones in conducting business transactions. Moreover, the inhibiting factor of MSMEs in utilizing social media and market places is the inability of businesses to operate and optimize social media and market places in their business strategies.

\section{Recommendations}

Based on the findings, intensive training is needed for MSME entrepreneurs in Sanan-Malang City provided by the government, academics, and other parties regarding the optimization and utilization of social media or marketplaces in an effort to improve market segmentation and their business innovation strategies. In addition, there is also a need to strengthen MSME actors' understanding of the importance of business strategy innovation in maintaining business survival from disruption and new business models that continue to develop rapidly

\section{REFERENCES}

Alberti-Alhtaybat L. v. Al-Htaybat K, Hutaibat K. 2019. A knowledge management and sharing business model for dealing with disruption: The case of Aramex. Journal of Business Research 94:400-407. https://doi.org/10.1016/j. jbusres.2017.11.037.

Assink M. 2006. Inhibitors of disruptive innovation capability:Aconceptualmodel.European Journal of Innovation Management 9(2): 215-233. https://doi.org/10.1108/14601060610663587

BPS Kota Malang. 2018. Kota Malang dalam Angka. Malang: BPS Kota Malang.

Deny S. 2018. Baru 9 Persen UMKM RI yang Masuk E-Commerce. Liputan 6. https://www.liputan6. com/bisnis/read/3582327/baru-9-persen-umkmri-yang-masuk-e-commerce.

Francesco C, Scuotto V, Carayannis E, Cillo V. 2018. Intertwining the internet of things and consumers' behaviour science: Future promises for businesses. Technological Forecasting and Social Change 136: 277-284. https://doi. org/10.1016/j.techfore.2018.03.019

Habtay SR. 2012. A Firm-Level Analysis on the Relative Difference between TechnologyDriven and Market-Driven Disruptive Business Model Innovations: Disruptive business model innovation. Creativity and Innovation Management 21(3): 290-303. https://doi. org/10.1111/j.1467-8691.2012.00628.x.

Hakim L. 2018. Pertumbuhan perekonomian Jatim andalkan sektor UMKM. Sindonews.Com. https://jatim.sindonews.com/read/739/1/ pertumbuhan-perekonomian-jatim-andalkansektor-umkm-1534558134.

Hanum AN. 2017. Analisis Faktor-Faktor yang Mempengaruhi Adopsi E-Commerce dan Pengaruhnya terhadap Kinerja UMKM (Studi Kasus UMKM di Wilayah Kota Semarang). MAKSIMUM: Media Akuntansi Universitas Muhammadiyah Semarang 1(1): 1-15.

Hartati D. 2011. Penerapan XML Web service Pada Sistem Distribusi Barang. Jurnal Generic 6(2):55-62.

Hopp C, Antons D, Kaminski J, Salge TO. 2018. The topic landscape of disruption research-A call for consolidation, reconciliation, and generalization: The topic landscape of disruption research. Journal of Product Innovation Management 35(3): 458-487. https://doi.org/10.1111/ jpim. 12440.

Idris I. 2019. Exploring organizational culture, quality assurance, and performance in higher education. Management and Economics Journal (MEC-J) 3(2): 166-181. https://doi.org/10.18860/mec-j. v3i2.7529.

Idris I, Adi KR. 2019. Transformational Leadership and Team Performance: The Role of Innovation in Indonesia Property Agent Industry. Proceedings of the 2018 International Conference on Islamic Economics and Business (ICONIES 2018), 334- 
338. https://doi.org/10.2991/iconies-18.2019.67. Kasali R. 2018. Disruption; Menghadapi lawan-lawan tak kelihatan dalam peradaban Uber. Jakarta: PT. Gramedia Pustaka Utama.

Kim SH. 2006. Impact of Mobile-Commerce: Bennefit, Technological, and Strategic Issue and Implementation. Jurnal of Applied Sciences 6(12): 2523-2531.

Lim EP, Shen Z, Siau K. 2003. Mobile Commerce: Current States and Future Trends. Idea Group Publishing.

Markides C. 2006. Disruptive Innovation: In Need of Better Theory. Journal of Product Innovation Management 23(1): 19-25. https://doi. org/10.1111/j.1540-5885.2005.00177.x

Miles M, Huberman M. 1994. Qualitative Data Analysis: An Expanded Sourcebook (2nd ed.). Thousand Oaks: Sage.

Nauwelaerts Y, Chakri S. 2016. The role of e-commerce and $\mathrm{m}$-commerce in the international strategy of fashion companies: a qualitative research in the belgian fashion industry. Journal of Creativity and Business Innovation 2: 80-113.

Nieuwenhuis LJM, Ehrenhard ML, Prause L. 2018. The shift to cloud computing: the impact of disruptive technology on the enterprise software business ecosystem. Technological Forecasting and Social Change 129: 308-313. https://doi. org/10.1016/j.techfore.2017.09.037

Niranjanamurthy $M$, Kavyshree $N$, Jagannath D, Chahar D. 2013. Analysis of e-commerce and $\mathrm{m}$-commerce: advantages, limitations and security issues. International Journal of Advance Research in Computer and Communication Engineering 2(6): 2360-2370.

Nugraha AEP. 2018. Pengelolaan dan strategi UMKM di era disrupsi digital. Proceeding Seminar Nasional 887-890.

PrabandariSP,Azzuhri M. 2011.Efektivitas penggunaan e-commerce sebagai penunjang aktivitas bisnis pada usaha kecil menengah (UKM) di Malang Raya. Jurnal Aplikasi Manajemen 9(2): 320328.

Priambada S. 2015. Manfaat penggunaan media sosial pada usaha kecil menengah (UKM). Seminar Nasional Sistem Informasi Indonesia, 41-46. http://is.its.ac.id/pubs/oajis/index.php/file/ download_file/1547

Purwadita CP, Sudiro A, Mugiono M, Idris I. 2018. Innovation in leadership and team performance: Evidence from indonesia property agent industry.
Management and Economics Journal (MEC-J) 2(2): 133-151. http://dx.doi.org/10.18860/mec-j. v0i1.5221

Rahmana A. 2009. Peranan teknologi informasi dalam peningkatan daya saing UKM. Seminar Nasional Aplikasi Teknologi Informasi 2009 (SNATI 2009), B11-B15. http://journal.uii.ac.id/index. php/Snati/article/viewFile/1033/989

Rahmidani R. 2015. Penggunaan e-commece dalam bisnis sebagai sumber keunggulan bersaing perusahaan [Thesis]. Padang: Universitas Negeri Padang.

Roy A, Zalzala AMS, Kumar A. 2016. Disruption of things: A model to facilitate adoption of IoTbased innovations by the urban poor. Procedia Engineering 159: 199-209. https://doi. org/10.1016/j.proeng.2016.08.159

Sani A, Wekke IS, Ekowati VM, Abbas B, Idris I. 2018. Moderation effect of workplace spirituality on the organizational citizenship behavior. International Journal of Applied Business and Economic Research 16(2): 455-465.

Sani A, Ekowati VM, Wekke IS, Idris I. 2018. Respective contribution of entrepreneurial leadership through organizational citizenship behavior In creating employees performance. Academy of Entrepreneurship Journal 24(4): 1-11.

Schumpeter. 1934. The Theory of Economic Development: An Inquiry into Profits, Capital, Credits, Interest, and the Business Cycle. Transaction Publishers.

Shin D. 2017. An exploratory study of innovation strategies of the internet of things SMEs in South Korea. Asia Pacific Journal of Innovation and Entrepreneurship 11(2): 171-189. https://doi. org/10.1108/APJIE-08-2017-025

Siswanto T. 2013. Optimalisasi sosial media sebagai media pemasaran usaha kecil menengah. Jurnal Liquidity 2(1): 80-86. https://doi.org/10.32546/ lq.v2i1.134

Sugiyono. 2017. Metode Penelitian Kuantitatif, Kualitatif, dan $R \& D$ (26th ed.). Alfabeta.

Tidd J. 2001. Innovation Management in context; environment, organization and performance. International Journal of Management Reviews 3(3): $169-183$.

Wahyunik S. 2017. UMKM Jadi Kontributor Pertumbuhan Ekonomi Kota Malang. Suryamalang. Tribunnews.Com.http:// suryamalang.tribunnews.com/2017/04/27/ umkm-jadi-kontributor-pertumbuhan-ekonomi- 
kota-malang [ 27 April 2017]

Widiarini AD. 2018. Kemkominfo ajak UMKM maksimalkan E-commerce. Kompas. https://ekonomi.kompas.com/ $\mathrm{read} / 2018 / 09 / 28 / 151900826 /$ kemkominfoajak-umkm-maksimalkan-e-commerce $[28 \mathrm{sept}$
2018].

Widyaningrum PW. 2016. Peran media sosial sebagai strategi pemasaran pada sewa kostum Meiyu Aiko Malang. Al Tijarah 2(2): 230-257. http:// dx.doi.org/10.21111/tijarah.v2i2.744 